\title{
Interactive effects of planting method and zeolite application on yield attributes of chickpea (Cicer arietinum L.) in dryland conditions
}

\author{
Seyyed Shahaboddin $\operatorname{HOSEINI}^{1}$, Asad ROKHZADI ${ }^{1,2}$, Ezzat KARAMI ${ }^{1}$
}

Received May 4, 2019; accepted January 15, 2020.

Delo je prispelo 4. maja 2019, sprejeto 15. junija 2020.

\begin{abstract}
Interactive effects of planting method and zeolite application on yield attributes of chickpea (Cicer arietinum L.) in dryland conditions

Abstract: Adopting an appropriate planting method and application of soil amendments such as zeolite in dryland conditions could be highly effective in improving growth and productivity of crop plants. Therefore the response of two chickpea (Cicer arietinum L.) genotypes (Azad and Adel) to two planting methods (flat and furrow patterns) and different rates of zeolite $\left(0,10\right.$ and $\left.20 \mathrm{t} \mathrm{ha}^{-1}\right)$ was examined in a field study under dryland conditions. Zeolite application increased plant height, pods number/plant and seed yield, under flat planting pattern, while in furrow pattern, chickpea yield decreased with the application of zeolite. Under no zeolite condition, sowing in furrows improved plant height and pods number compared with flat sowing. Zeolite had no effect on Azad cultivar, but the pods number/plant of Adel was significantly increased by applying $20 \mathrm{t} \mathrm{ha}^{-1}$ zeolite compared with control. In general, the best result in terms of crop growth and yield was obtained from applying $20 \mathrm{t} \mathrm{ha}^{-1}$ zeolite in flat planting pattern. Positive response of the plant to zeolite application in flat planting pattern and, on the other hand, the yield reduction resulting from zeolite addition in furrow planting condition suggested that the influence of zeolite on the crop was dependent on planting method.

Key words: flat planting; furrow planting; dryland farming; zeolite
\end{abstract}

Medsebojni vpliv sejalnih metod in uporabe zeolita na komponente pridelka čičerke (Cicer arietinum L.) v sušnih razmerah

Izvleček: Uporaba primernih metod setve in dodatkov zeolita v tla bi lahko bili zelo učinkoviti ukrepi za izboljšanje rasti in povečanja pridelka poljščin v sušnih razmerah. $\mathrm{V}$ ta namen je bil ovrednoten odziv dveh genotipov čičerke (Cicer arietinum 'Azad', 'Adel') v poljskem poskusu z dvema načinoma setve (setev na ravno površino in setev $\mathrm{v}$ brazde)) ob različnih dodatkih zeolita $\left(0,10\right.$ in $\left.20 \mathrm{t} \mathrm{ha}^{-1}\right) \mathrm{v}$ sušnih razmerah. Uporaba zeolita je povečala višino rastlin, število strokov na rastlino in pridelek semena pri setvi na ravno površino medtem, ko se je pridelek čičerke pri setvi v brazde in dodatku zeolita zmanjšal. Pri dodatku zeolita se je pri setvi v brazde povečala višina rastlin in število strokov na rastlino $\mathrm{v}$ primerjavi s setvijo na ravno površino. Zeolit ni imel nobenega učinka na sorto Azad, pri sorti Adel pa se je število strokov na rastlino značilno povečalo pri dodatku zeolita $20 \mathrm{t} \mathrm{ha}^{-1} \mathrm{v}$ primerjavi s kontrolo. Nasplošno so bili doseženi najboljši rezultati glede rasti in pridelka poljščine pri dodatku zeolita $20 \mathrm{t} \mathrm{ha}^{-1}$ in pri setvi na ravno površino. Pozitivni odziv rastlin ob dodatku zeolita pri setvi na ravno površino in upad pridelka ob setvi v brazde kažeta, da je vpliv zeolita na uspevanje poljščine odvisen od načina setve.

Ključne besede: setev na ravno površino; setev v brazde; kmetovanje na sušnih območjih; zeolit

1 Islamic Azad University, Faculty of Agriculture, Sanandaj Branch, Department of Agronomy and Plant Breeding, Sanandaj, Iran

2 Corresponding author, e-mail: asadrokh@yahoo.com 


\section{INTRODUCTION}

Chickpea (Cicer arietinum L.) is the second most important grain legume in the world with the harvest area of about 14.56 million ha, and in Iran is the most important food legume grown on 0.566 million ha with the annual production of 0.271 million tons (FAO, 2017). More than $97 \%$ of chickpea in Iran is cultivated under rain-fed conditions and grown on stored soil moisture (Anonymous, 2017). Therefore, the application of any kind of technique or method that would increase the chickpea production efficiency in dryland conditions can be recommended. Selecting a proper planting pattern plays an important role in improving the growth and yield of crop plants especially in dryland farming and water deficit conditions.

Different cultivation techniques including two methods of flat and furrow planting have been studied and compared by many researchers. Results of a study on the effects of furrowing the soil surface on barley yield and soil water storage revealed that the application of deep furrow techniques had a positive effect on water storage and availability in soil leading to a significant increase in grain and straw yield of barley as compared with the natural (not furrowed) soil surface treatment (Abu-Awwad \& Kharabsheh, 2000). Comparison of three planting systems of RP (ridge planting), FRP (flat planting with ridging at early jointing stage) and FP (flat planting without ridging) in rain-fed conditions showed that corn growth and yield in FRP system were significantly higher than those in RP and FP systems due to the improvement of soil moisture and temperature under FRP system (Song et al., 2013). Implementation of ridgefurrow planting system along with mulching techniques in semiarid conditions led to a significant increase in dry matter, grain yield and water use efficiency of corn compared with conventional flat farming (Ren et al., 2010). In an experiment the effects of three seed bed patterns including flat sowing (T1), raised bed with pair row of crop at $20 \mathrm{~cm}$ spacing on one bed and $40 \mathrm{~cm}$ furrow width (T2) and raised bed with pair row of crop at $30 \mathrm{~cm}$ spacing on one bed with $50 \mathrm{~cm}$ furrow width (T3) on chickpea were studied and the results showed that treatment $\mathrm{T} 3$ was superior to T1 and T2 in terms of pods number per plant, grain yield and growth parameters such as plant height and nodulation (Bhargav et al., 2018). Pourghasemian and Zahedi (2009) reported that the flat planting method compared to furrow method significantly increased seed yield, yield components, harvest index and seed oil content of safflower. Also, in a study carried out by Montazar et al. (2014), the planting method did not have a significant effect on any of the studied traits in wheat.

Preservation and storage of soil moisture in dry- land farming conditions is of great importance. Zeolites are a large group of aluminosilicate mineral compounds with useful properties including absorbing and releasing water, high porosity and high cation exchange capacity, which are applied in agriculture to improve soil conditions (Mumpton, 1999; Eroglu et al., 2017). Zeolites improve the water use efficiency of plants by increasing the water holding capacity of soil and facilitating the transfer of water to plant roots (Sangeetha \& Baskar, 2016). Zeolites can improve plant growth and increase its yield by storing and maintaining nutrients and releasing them at the right time and in a gradual manner (Polat et al., 2004). The beneficial effects of zeolite application on crops, especially under water-limited conditions have been reported in many studies (Mahmoodabadi et al., 2009; Aghaalikhani et al., 2012; Gholamhosseini et al., 2013; Najafinezhad et al., 2015; Ozbahce et al., 2015).

Although many studies have been done on the effects of planting techniques and zeolite application on different crops, there is no report on the interaction between planting method and application of zeolite in dryland conditions on chickpea. Therefore, the present study was conducted to investigate the growth and yield response of two chickpea cultivars to the application of different amounts of zeolite in two systems of flat and furrow planting under dryland conditions.

\section{MATERIALS AND METHODS}

\subsection{EXPERIMENTAL SITE DESCRIPTION}

This experiment was carried out during 2015-2016 growing season in Kamyaran county, Kurdistan province, west of Iran. The experimental farm is located at a latitude of $34^{\circ} 47^{\prime} \mathrm{N}$ and longitude of $46^{\circ} 53^{\prime} \mathrm{E}$ with an elevation of $1425 \mathrm{~m}$ above sea level. The long-term annual precipitation and mean temperature of the region are $464.5 \mathrm{~mm}$ and $14.4{ }^{\circ} \mathrm{C}$ respectively. The monthly precipitation and temperature of the site in the growing season and the characteristics of farm soil are shown in Fig. 1 and Table 1 respectively.

\subsection{EXPERIMENT LAYOUT AND MANAGEMENT}

The experiment was conducted in a factorial arrangement with three factors based on a randomized complete block design in three replications under dryland conditions. The first factor was planting method including two patterns of flat and furrow, the second factor was zeolite application rate $\left(0,10\right.$ and $20 \mathrm{t} \mathrm{ha}^{-1}$ as Z0, Z10 and $\mathrm{Z} 20$ respectively) and two Kabuli type chickpea cul- 


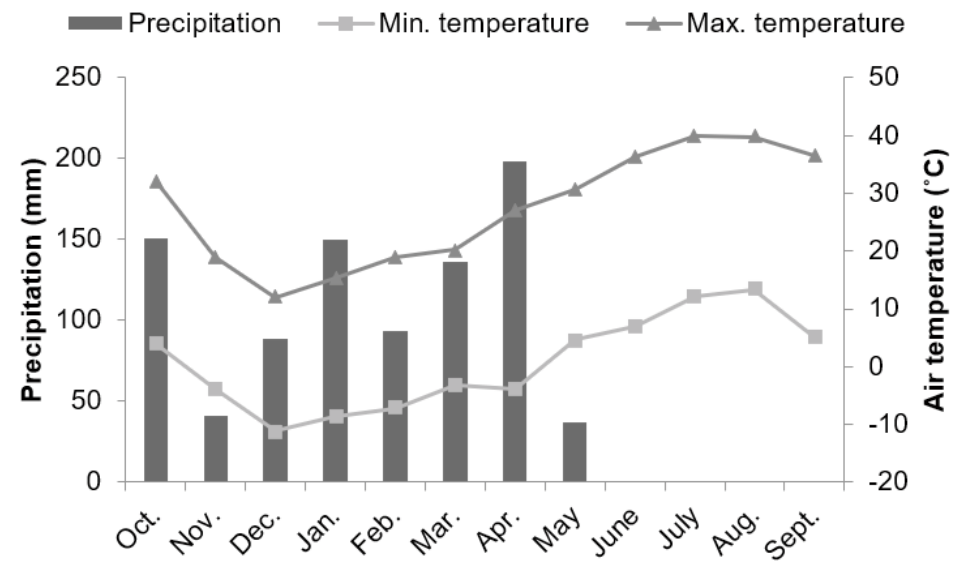

Figure 1: Precipitation and temperature during the growing season of 2015-2016 at the experimental site

Table 1: Soil properties of the experimental site

\begin{tabular}{llllllllll}
\hline $\begin{array}{l}\text { Clay } \\
(\%)\end{array}$ & $\begin{array}{l}\text { Silt } \\
(\%)\end{array}$ & $\begin{array}{l}\text { Sand } \\
(\%)\end{array}$ & $\begin{array}{l}\text { OC } \\
(\%)\end{array}$ & $\begin{array}{l}\text { TNV } \\
(\%)\end{array}$ & $\mathrm{pH}$ & $\begin{array}{l}\mathrm{EC} \\
\left.(\mathrm{dS} \mathrm{m})^{-1}\right)\end{array}$ & $\begin{array}{l}\mathrm{N} \\
(\%)\end{array}$ & $\begin{array}{l}\mathrm{P} \\
(\mathrm{ppm})\end{array}$ & $\begin{array}{l}\mathrm{K} \\
(\mathrm{ppm})\end{array}$ \\
\hline 32.72 & 51.28 & 16 & 0.74 & 9.25 & 7.85 & 0.511 & 0.08 & 9.8 & 220 \\
\hline
\end{tabular}

$\mathrm{OC}=$ Organic carbon, $\mathrm{TNV}=$ Total neutralizing value, $\mathrm{EC}=$ Electrical conductivity

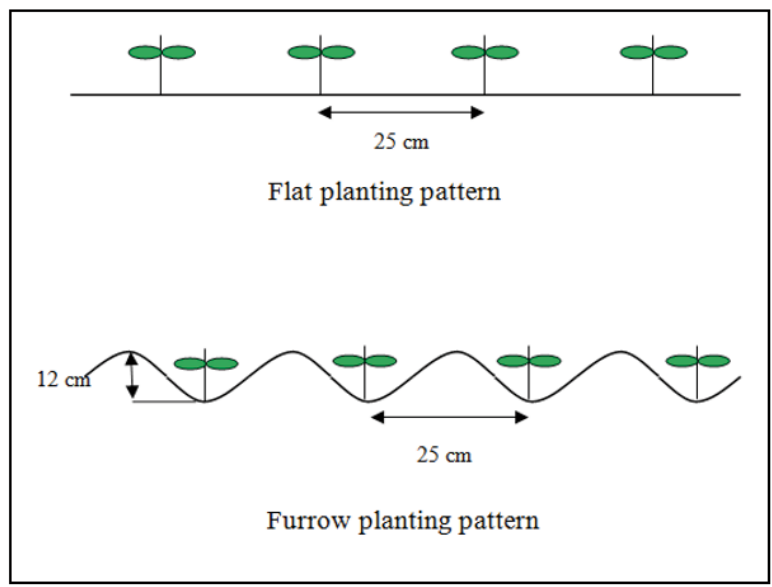

Figure 2: Schematic diagram of the two planting patterns

tivars of Azad and Adel were studied as the third factor items. Each experimental plot contained four rows, $3 \mathrm{~m}$ in length, $0.25 \mathrm{~m}$ apart and the space between the plants on each row was $10 \mathrm{~cm}$. The fertilizers of urea, triple superphosphate and potassium sulfate were used before planting at the rates of 60,35 and $25 \mathrm{~kg} \mathrm{ha}^{-1}$ respectively according to the soil analysis results. The natural zeolite of clinoptilolite in relevant rates was applied in the seed bed prior to sowing. The seeds of chickpea were treated with benomyl fungicide before sowing to prevent soilborne diseases. In flat planting pattern the seeds were sown at a depth of $3-5 \mathrm{~cm}$ and in furrow planting pat- tern were sown at the same depth in the middle of the furrows. The width and depth of furrows were 25 and $12 \mathrm{~cm}$ respectively (Fig. 2). The operation of sowing was performed manually in mid-March. The experiment was done under dryland conditions with no irrigation and hand weeding was performed at different growth stages of the plant.

\subsection{DATA COLLECTING}

Different crop traits including plant height, number 
of primary and secondary branches per plant, pods number per plant, seeds number per pod, 100 -seed mass and seed yield were studied in the experiment. The morphological characteristics of the plant and yield components were measured using seven randomly harvested plants in each plot. The seed yield in each plot was determined by hand-harvesting the central two rows of the plot.

\subsection{STATISTICAL ANALYSIS}

The measured data were subjected to analysis of variance (ANOVA) and when the ANOVA result was significant, the least significant difference (LSD) test was done for means separation. The statistical operations were performed using SAS software (SAS Institute Inc., Cary, NC, USA).

\section{RESULTS AND DISCUSSION}

\subsection{PLANT HEIGHT AND NUMBER OF BRANCH- ES}

The plant height at maturity stage was significantly affected by the interaction of planting pattern and zeolite application but the number of primary and secondary branches per plant was not affected by the experimental factors and their interactions (Table 2). A significant increase in plant height was recorded by using $20 \mathrm{tha}^{-1}$ zeolite compared with Z0 (control) and Z10 treatments in flat planting pattern, whereas the plant did not respond to the application of zeolite in terms of plant height under furrow planting pattern (Fig. 3). Moreover, it can be seen that the plant height in furrow planting was higher than that in flat planting under the Z0 treatment (Fig. 3).

Table 3: Impact of planting pattern, zeolite application and cultivar on growth and yield parameters

\begin{tabular}{|c|c|c|c|c|c|c|c|}
\hline Treatments & $\begin{array}{l}\text { Plant height } \\
(\mathrm{cm})\end{array}$ & $\begin{array}{l}\text { Primary } \\
\text { branches } \\
\text { plant }^{-1}\end{array}$ & $\begin{array}{l}\text { Secondary } \\
\text { branches } \\
\text { plant }^{-1}\end{array}$ & $\begin{array}{l}\text { Pods no } \\
\text { plant }^{-1}\end{array}$ & $\begin{array}{l}\text { Seeds no } \\
\text { pod }^{-1}\end{array}$ & $\begin{array}{l}100 \text {-seed mass } \\
(\mathrm{g})\end{array}$ & $\begin{array}{l}\text { Seed yield } \\
\left(\mathrm{kg} \mathrm{ha}^{-1}\right)\end{array}$ \\
\hline \multicolumn{8}{|l|}{ Planting pattern } \\
\hline Flat & $35.0 \pm 0.8$ & $3.2 \pm 0.09$ & $9.9 \pm 0.68$ & $36.4 \pm 1.8$ & $1.19 \pm 0.05$ & $24.2 \pm 0.9$ & $1258.7 \pm 48.4$ \\
\hline Furrow & $35.5 \pm 0.4$ & $3.1 \pm 0.07$ & $10.4 \pm 0.56$ & $33.6 \pm 1.2$ & $1.17 \pm 0.03$ & $24.4 \pm 0.9$ & $1052.4 \pm 65.4$ \\
\hline$L S D_{0.05}$ & 1.43 & 0.23 & 1.52 & 2.18 & 0.11 & 2.32 & 131.14 \\
\hline \multicolumn{8}{|l|}{ Zeolite rate } \\
\hline $\mathrm{Z} 0$ & $34.4 \pm 0.7$ & $3.3 \pm 0.13$ & $10.3 \pm 0.72$ & $33.6 \pm 1.9$ & $1.18 \pm 0.06$ & $25.2 \pm 1.5$ & $1193.5 \pm 82.8$ \\
\hline $\mathrm{Z} 10$ & $34.9 \pm 0.8$ & $3.0 \pm 0.08$ & $9.8 \pm 0.64$ & $33.5 \pm 1.0$ & $1.18 \pm 0.06$ & $23.9 \pm 0.8$ & $1103.8 \pm 54.4$ \\
\hline $\mathrm{Z} 20$ & $36.5 \pm 0.7$ & $3.2 \pm 0.09$ & $10.3 \pm 0.93$ & $37.9 \pm 2.4$ & $1.18 \pm 0.04$ & $23.8 \pm 0.6$ & $1169.4 \pm 89.6$ \\
\hline$L S D_{0.05}$ & 1.75 & 0.28 & 1.86 & 2.67 & 0.14 & 2.84 & 160.62 \\
\hline \multicolumn{8}{|l|}{ Cultivar } \\
\hline Azad & $35.1 \pm 0.6$ & $3.2 \pm 0.09$ & $10.3 \pm 0.75$ & $36.2 \pm 1.4$ & $1.17 \pm 0.03$ & $25.7 \pm 0.9$ & $1237.1 \pm 67.5$ \\
\hline Adel & $35.5 \pm 0.6$ & $3.1 \pm 0.07$ & $10.1 \pm 0.46$ & $33.8 \pm 1.7$ & $1.19 \pm 0.05$ & $22.9 \pm 0.9$ & $1074.1 \pm 50.3$ \\
\hline$L S D_{0.05}$ & 1.43 & 0.23 & 1.52 & 2.18 & 0.11 & 2.32 & 131.14 \\
\hline \multicolumn{8}{|l|}{$\begin{array}{l}\text { Source of varia- } \\
\text { tion }\end{array}$} \\
\hline $\begin{array}{l}\text { Planting pattern } \\
\text { (P) }\end{array}$ & ns & ns & ns & * & ns & ns & $* *$ \\
\hline Zeolite (Z) & ns & ns & ns & $* *$ & ns & ns & ns \\
\hline Cultivar (C) & ns & ns & ns & * & ns & * & * \\
\hline $\mathrm{P} \times \mathrm{Z}$ & * & ns & ns & $* * *$ & ns & ns & $* *$ \\
\hline $\mathrm{P} \times \mathrm{C}$ & ns & ns & ns & $* *$ & ns & ns & ns \\
\hline $\mathrm{Z} \times \mathrm{C}$ & ns & ns & ns & * & ns & ns & ns \\
\hline $\mathrm{P} \times \mathrm{Z} \times \mathrm{C}$ & ns & ns & ns & ns & ns & ns & ns \\
\hline CV\% & 5.86 & 10.50 & 21.85 & 9.01 & 13.70 & 13.82 & 16.42 \\
\hline
\end{tabular}

ns: Not significant. ${ }^{*},{ }^{* *}$ and ${ }^{* * *}$ : Significant at the $0.05,0.01$ and 0.001 probability levels, respectively. Values are given as means \pm standard errors. 


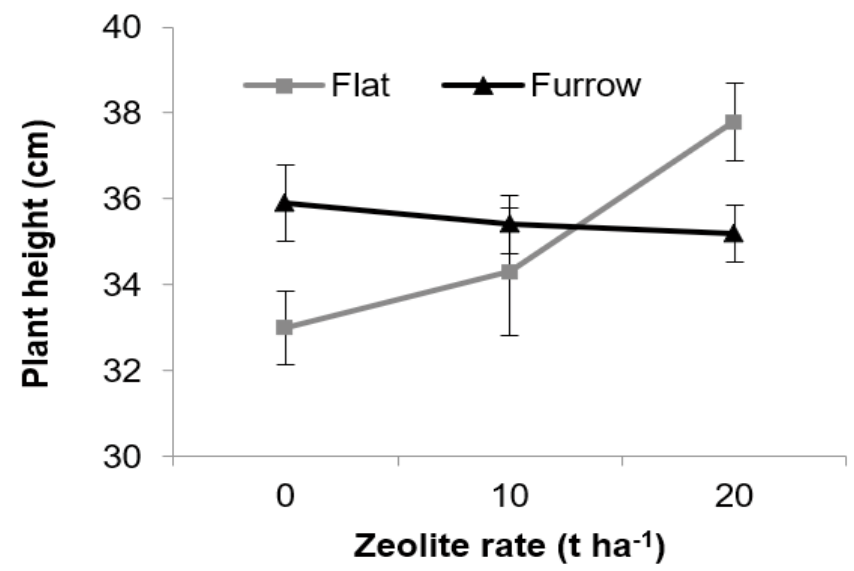

Figure 3: Interactive effect of planting pattern and zeolite application on plant height. Vertical bars indicate the standard error of the means

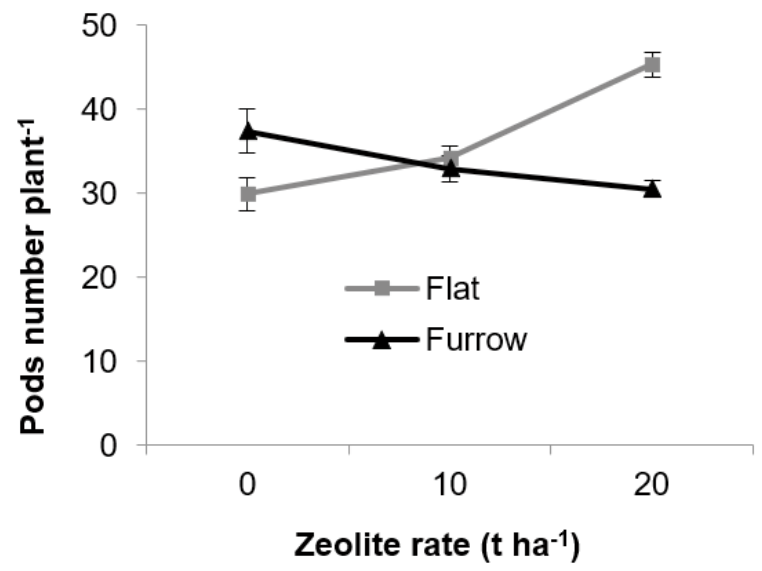

Figure 4: Interactive effect of planting pattern and zeolite application on pods number plant ${ }^{-1}$. Vertical bars indicate the standard error of the means

An increased plant height in chickpea is a desirable trait for the ease of mechanical harvesting (Patil et al., 2014). According to the results of present study, plant height of chickpea can be increased through the application of zeolite in conventional flat planting system. The increase in plant growth due to zeolite application may be attributed to the positive effects of zeolite on the availability of water and essential nutrients for the plant (Rehakova et al., 2004; Mahmoodabadi et al., 2009; Zahedi et al., 2009).

\subsection{YIELD COMPONENTS}

The interaction between planting method and zeolite application had a significant effect on pods number plant $^{-1}$ (Table 2). In the case of no zeolite application, the number of pods per plant in furrow system was higher than that in flat system (Fig. 4). Under flat planting pattern a significant increase in pods number was recorded by 14 and $52 \%$ through the application of 10 and $20 \mathrm{t}$ $\mathrm{ha}^{-1}$ zeolite respectively compared with $\mathrm{Z0}$, while in furrow system a decreasing trend was shown in pods number with the application of zeolite (Fig. 4).

The interactive effect of planting pattern and cultivar on pods number demonstrated that under flat planting pattern there was no significant difference between two chickpea cultivars but in furrow system the number of pods per plant in Azad was significantly higher than that in Adel (Fig. 5).

The pods number per plant was significantly affected by the zeolite $\times$ cultivar interaction (Table 2 ). The effect of zeolite application on pods number in Azad cultivar was not significant while Adel positively responded to zeolite, so that the pods number/plant in this genotype 


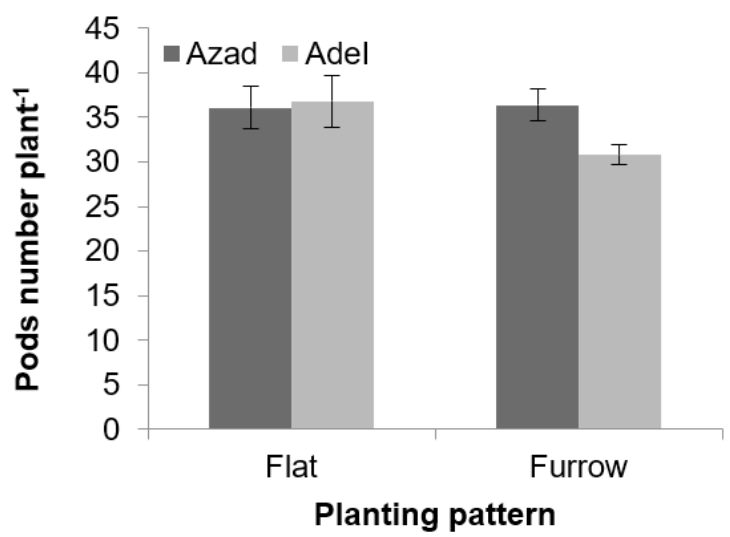

Figure 5: Interactive effect of planting pattern and cultivar on pods number plant ${ }^{-1}$. Vertical bars indicate the standard error of the means

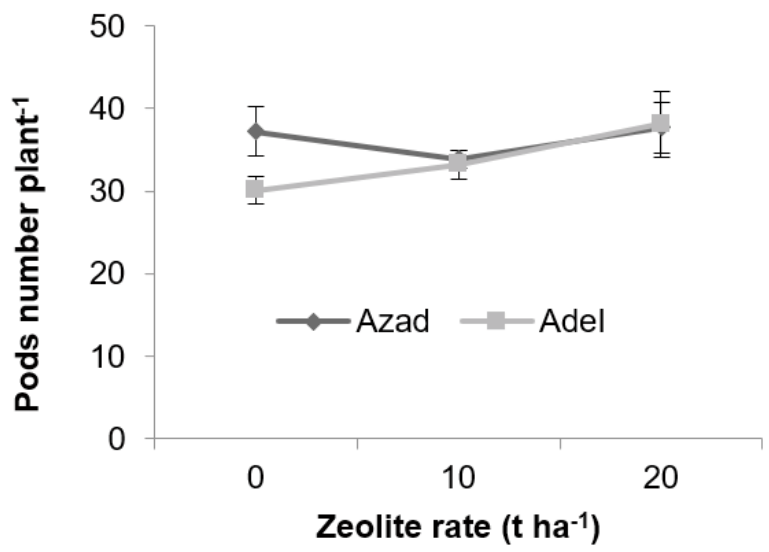

Figure 6: Interactive effect of zeolite application and cultivar on pods number plant ${ }^{-1}$. Vertical bars indicate the standard error of the means

was increased by 10 and $27 \%$ in Z10 and Z20 treatments, respectively, compared with control (Z0) treatment (Fig. 6). Our result regarding the different reaction of genotypes to zeolite application is consistent with that of $\mathrm{Za}$ hedi et al. (2009) who showed a significant interaction between zeolite and cultivar in canola. Different response of two chickpea cultivars to planting pattern and zeolite application in terms of pod production is an indication of different growth potential of genotypes under various agronomic practices.

Analysis of variance results indicated that number of seeds per pod was not affected by the experimental factors of planting pattern, zeolite, cultivar and their interactions (Table 2).

Planting method and zeolite application did not significantly affect the 100 -seed mass, but it was significantly influenced by cultivar factor (Table 2). Azad cultivar was superior to Adel by $12 \%$ in terms of 100 -seed mass (Table 2). The non-significance of zeolite and planting method effects on seed mass was similarly reported by Sepaskhah and Barzegar (2010) and Bhargav et al. (2018).

\subsection{SEED YIELD}

Seed yield was affected by planting pattern, cultivar and the interaction between planting pattern and zeolite (Table 2). Azad cultivar with seed yield of $1237 \mathrm{~kg} \mathrm{ha}^{-1}$ was significantly superior to Adel with $1074 \mathrm{~kg} \mathrm{ha}^{-1}$ seed yield (Table 2). Seed yield response to the interaction of planting method $\times$ zeolite showed that under the flat planting pattern, the application of zeolite led to seed yield improvement. The highest seed yield $\left(1407 \mathrm{~kg} \mathrm{ha}^{-1}\right)$ was obtained in Z20 treatment under flat pattern which 
was $21 \%$ higher than that of $\mathrm{Z} 0$ treatment (Fig. 7). On the other hand, under furrow method, seed yield decreased as the result of zeolite application (Fig. 7).

Our results regarding the positive effects of zeolite application on seed yield under conventional flat planting method are in line with those of previous studies. Zahedi et al. (2009) in a study on rapeseed showed that application of $10 \mathrm{t} \mathrm{ha}^{-1}$ zeolite under conditions that the crop is subjected to late season drought stress could improve the crop growth and yield. In another study, root and shoot dry mass and the content of micro and macro nutrients in roots and shoots of soybean were increased as the result of zeoilte application (Mahmoodabadi et al. 2009). The findings of Ozbahce et al. (2015) indicated that the application of zeolite significantly improved the concentration of different nutrients including nitrogen, potassium, zinc, manganese and copper in common bean leaves and increased the seed yield and yield components of the crop under water deficit stress conditions.

Seed yield reduction resulted from zeolite application under furrow planting pattern in current study may be related to the interaction between zeolite function and topology of the soil surface. In other words, the behavior of zeolite and its positive effects on crop growth can be affected by the shape of soil surface and the level of tillage operation. However, in order to better understand the performance of zeolite in each planting system, further studies, such as moisture and temperature measurements in different soil profiles and evaluation of soil nutrients availability in both planting patterns under the various amounts of zeolite are needed.

Under conditions of no zeolite application the response of chickpea to furrow sowing compared with flat planting pattern was more desirable in terms of plant height, pods number and seed yield (Fig. 3, 4 and 7), in- dicating the advantages of furrow planting over flat pattern with no zeolite application in dryland farming conditions. Several studies have shown that furrow sowing in dryland conditions has many benefits such as easily shedding of rain from ridges, accumulation of runoff in furrows, infiltration of rainwater below the furrow and better access of plant roots to sub-soil water (Yang et al., 1996; Feng et al., 2001; Ren et al., 2010; Roper et al., 2015) and improvement in growth and yield of various crops under furrow sowing compared with flat planting has been declared in many reports (Blackwell, 1993; Wang et al., 2011; Quanqi et al., 2012; Lian et al., 2016; Li et al., 2018).

\section{CONCLUSIONS}

Under flat planting pattern, plant height, pods number/plant and seed yield increased, whereas under furrow system, these traits decreased as the result of zeolite application. On the other hand, we found that under no zeolite condition, the furrow sowing had a positive effect on plant height and pods production. Genotypes comparison showed that Azad cultivar did not respond to zeolite application, while in Adel the pods number was increased due to zeolite application. In general, the findings of this study suggest that the effect of zeolite on chickpea growth and yield is dependent on seedbed configuration.

\section{REFERENCES}

Abu-Awwad, A. M. and Kharabsheh, A. A. (2000). Influence of supplemental irrigation and soil surface furrowing on barley yield in arid areas affected by surface crust. Journal

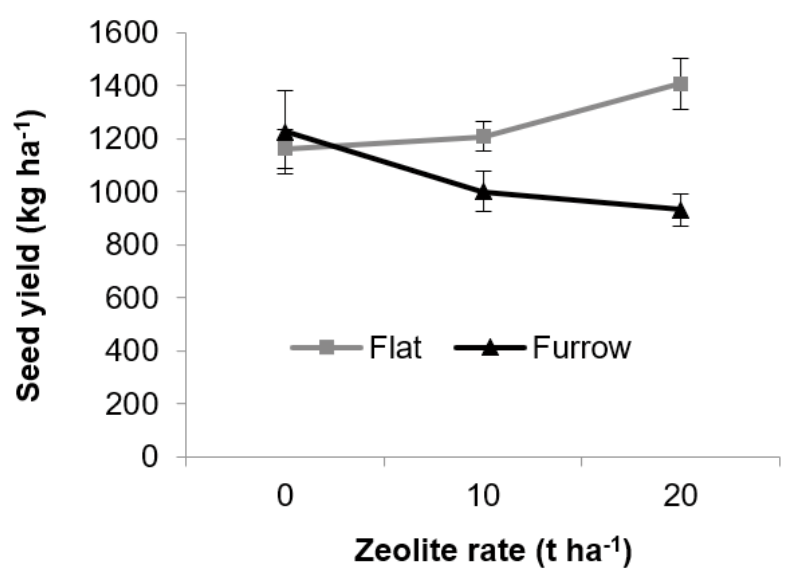

Figure 7: Interactive effect of planting pattern and zeolite application on seed yield. Vertical bars indicate the standard error of the means 
of Arid Environments, 46, 227-237. https://doi.org/10.1006/ jare. 2000.0673

Aghaalikhani, M., Gholamhoseini, M., Dolatabadian, A., Khodaei-Joghan, A. and Sadat Asilan, K. (2012). Zeolite influences on nitrate leaching, nitrogen-use efficiency, yield and yield components of canola in sandy soil. Archives of Agronomy and Soil Science, 58(10), 1149-1169. https://doi. org/10.1080/03650340.2011.572876

Anonymous. (2017). Annual Agricultural Statistics. Ministry of Agriculture of Iran. Retrieved from https://www.maj.ir

Bhargav, K. S., Gupta, N., Patel, N. and Pandey, A. (2018). Performance of chickpea (Cicer arietinum L.) sown on different seed bed configurations in Malwa region of Madhya Pradesh. Journal of Krishi Vigyan, 6(2), 172-175. https://doi. org/10.5958/2349-4433.2018.00008.9

Blackwell, P. (1993). Improving sustainable production from water repellent sands. Journal of the Department of Agriculture, Western Australia, 34(4), 160-167. https://researchlibrary.agric.wa.gov.au/journal_agriculture4/vol34/iss4/11

Eroglu, N., Emekci, M. and Athanassiou, C. G. (2017). Applications of natural zeolites on agriculture and food production. Journal of the Science of Food and Agriculture, 97(11), 3487-3499. https://doi.org/10.1002/jsfa.8312

FAO. (2017). Statistical Databases. Food and Agriculture Organization of the United Nations. Retrieved from http:// www.fao.org/faostat/en/

Feng, G. L., Letey, J. and Wu, L. (2001). Water ponding depths affect temporal infiltration rates in a water-repellent sand. Soil Science Society of America Journal, 65, 315-320. https:// doi.org/10.2136/sssaj2001.652315x

Gholamhoseini, M., Ghalavand, A., Khodaei-Joghan, A., Dolatabadian, A., Zakikhani, H. and Farmanbar, E. (2013). Zeolite-amended cattle manure effects on sunflower yield, seed quality, water use efficiency and nutrient leaching. Soil \& Tillage Research, 126, 193-202. https://doi.org/10.1016/j. still.2012.08.002

Li, C., Li, Y., Li, Y. and Fu, G. (2018). Cultivation techniques and nutrient management strategies to improve productivity of rain-fed maize in semi-arid regions. Agricultural Water Management, 210, 149-157. https://doi.org/10.1016/j. agwat.2018.08.014

Lian, Y., Ali, S., Zhang, X., Wang, T., Liu, Q., Jia, Q., Jia, Z. and Han, Q. (2016). Nutrient and tillage strategies to increase grain yield and water use efficiency in semi-arid areas. $A g$ ricultural Water Management, 178, 137-147. https://doi. org/10.1016/j.agwat.2016.09.021

Mahmoodabadi, M. R., Ronaghi, A., Khayyat, M. and Hadarbadi, Gh. (2009). Effects of zeolite and cadmium on growth and chemical composition of soybean (Glycine max L.). Tropical and Subtropical Agroecosystems, 10, 515-521. http://www.revista.ccba.uady.mx/ojs/index.php/TSA/article/view/229/153

Montazar, M. R., Zakerinia, M. and Moghaddasi, O. A. (2014). Investigation of the effect of periodic water stress and cultivation methods on irrigated wheat yield. Iranian Journal of lrrigation and Drainage, 4(7), 478-484 (In Persian with English abstract).

Mumpton, F. A. (1999). La roca magica: Uses of natural zeolites in agriculture and industry. Proceedings of the National
Academy of Sciences of the United States of America, 96, 3463-3470. https://doi.org/10.1073/pnas.96.7.3463

Najafinezhad, H., Tahmasebi Sarvestani, Z., Modarres Sanavy, S. A. M. and Naghavi, H. (2015). Evaluation of yield and some physiological changes in corn and sorghum under irrigation regimes and application of barley residue, zeolite and superabsorbent polymer. Archives of Agronomy and Soil Science, 61(7), 891-906. https://doi.org/10.1080/03650 340.2014 .959938

Ozbahce, A., Tari, A. F., Gönülal, E., Simsekli, N. and Padem, H. (2015). The effect of zeolite applications on yield components and nutrient uptake of common bean under water stress. Archives of Agronomy and Soil Science, 61(5), 615626. https://doi.org/10.1080/03650340.2014.946021

Patil, S. B., Mansur, C. P., Gaur, P. M., Goyal, A. and Alagundagi, S. C. (2014). Machine harvest: an economical method of chickpea harvesting. In: $6^{\text {th }}$ International Food Legume Research Conference and $7^{\text {th }}$ International Conference on Legume Genetic and Genomics, July 7-11, 2014. Saskatoon, Saskatchewan, Canada.

Polat, E., Karaca, M., Demir, H. and Onus, A. N. (2004). Use of natural zeolite (clinoptilolite) in agriculture. Journal of Fruit and Ornamental Plant Research, 12, 183-189. http://www.insad.pl/files/journal_pdf/journal_2004spec/ full2004-22spec.pdf

Pourghasemian, N. and Zahedi, M. (2009). Effects of planting pattern and level of soil moisture on yield and yield components of two safflower cultivars in Isfahan. Journal of Crop Production and Processing, 13(47), 545-555 (In Persian with English abstract). http://jcpp.iut.ac.ir/article-1-1075-en. html

Quanqi, L., Xunbo, Z., Yuhai, C. and Songlie, Y. (2012). Water consumption characteristics of winter wheat grown using different planting patterns and deficit irrigation regime. Agricultural Water Management, 105, 8-12. https://doi. org/10.1016/j.agwat.2011.12.015

Rehakova, M., Cuvanova, S., Dzivak, M., Rimar, J. and Gavalova, Z. (2004). Agricultural and agrochemical uses of natural zeolite of the clinoptilolite type. Current Opinion in Solid State and Materials Science, 8, 397-404. https://doi. org/10.1016/j.cossms.2005.04.004

Ren, X., Chen, X. and Jia, Z. (2010). Effect of rainfall collecting with ridge and furrow on soil moisture and root growth of corn in semiarid northwest China. Journal of Agronomy \& Crop Science, 196, 109-122. https://doi.org/10.1111/j.1439037X.2009.00401.X

Roper, M. M., Davies, S. L., Blackwell, P. S., Hall, D. J. M., Bakker, D. M., Jongepier, R. and Ward, P. R. (2015). Management options for water-repellent soils in Australian dryland agriculture. Soil Research, 53, 786-806. https://doi. org/10.1071/SR14330

Sangeetha, C. and Baskar, P. (2016). Zeolite and its potential uses in agriculture: A critical review. Agricultural Reviews, 37(2), 101-108. https://doi.org/10.18805/ar.v0iof.9627

Sepaskhah, A. R. and Barzegar, M. (2010). Yield, water and nitrogen use response of rice to zeolite and nitrogen fertilization in a semi-arid environment. Agricultural Water Management, 98, 38-44. https://doi.org/10.1016/j.agwat.2010.07.013 
Song, Z., Guo, J., Zhang, Z., Kou, T., Deng, A., Zheng, C., Ren, J. and Zhang, W. (2013). Impacts of planting systems on soil moisture, soil temperature and corn yield in rainfed area of Northeast China. European Journal of Agronomy, 50, 66-74. http://dx.doi.org/10.1016/j.eja.2013.05.008

Wang, T. C., Wei, L., Wang, H. Z., Ma, S. C. and Ma, B. L. (2011). Responses of rainwater conservation, precipitation-use efficiency and grain yield of summer maize to a furrow-planting and straw-mulching system in northern China. Field Crops Research, 124, 223-230. https://doi.org/10.1016/j. fcr.2011.06.014
Yang, B., Blackwell, P. S. and Nicholson, D. F. (1996). A numerical model of heat and water movement in furrow-sown water repellent sandy soils. Water Resources Research, 32(10), 3051-3061. https://doi.org/10.1029/96WR02103

Zahedi, H., Noormohammadi, G., Shiranirad, A. H., Habibi, D. and Akbarboojar, M. M. (2009). Effect of zeolite and foliar application of selenium on growth, yield and yield component of three canola cultivar under conditions of late season drought stress. Notulae Scientia Biologicae, 1(1), 73-80. http://dx.doi.org/10.15835/nsb113500 